Weisberg that my essay encourages "less the recasting than the continuation of what has been most provocative in the work already out there" (though we may disagree about what has been most provocative). But I certainly don't want (as Weisberg asserts I do) to "liberate narrators of all stripes to participate fully and positively in the political world," unless "positively" is seen as a modifier sufficiently powerful to convert "narrators of all stripes" into those whose specific participation I would welcome.

Julie Stone Peters Columbia University

\section{The Fate of Critical Terms}

\section{To THE EDITOR:}

Regarding the Editor's Column in the October issue ("What's Wrong with These Terms? A Conversation with Barbara Kirshenblatt-Gimblett and Diana Taylor" [120 (2005): 1497-1508]): in a literary universe, it's not surprising that representation has become so broadly applied that it refers to almost everything. This seems to be the fate of many successful critical terms, which come to embody far more than a trope, all the way to a mode of thinking or even a whole outlook. For instance, it's been remarked (a few too many times) that we live in an ironic age. And when the average English graduate student says, "Let's deconstruct that," but simply means to analyze it, something similar has occurred with Derrida.

But the trend isn't so much an occasion for hand-wringing as it is a reflection on the evolution of language. An individual pioneers a term, a group appropriates it, the masses popularize it, and it's time for the thinkers to come up with something new.

Paradoxically, the moment of a term's greatest currency is when it's almost denuded of meaning. Over a decade ago, when the word postmodern seemed to be part of every fifth book title exhibited at the MLA convention, any discerning critic should have realized that it was time to move on.

David Galef University of Mississippi

\section{The State of United States Southern Literary Studies}

\section{To THE EDITOR:}

The review essays in the Changing Profession section of $P M L A$ provide a welcome addition to the journal. In "Writing the New Middle Ages" (120 [2005]: 422-41), for example, Stephen G. Nichols offers a model essay celebrating the changes in a field that remained traditional for longer, perhaps, than some others. Unfortunately, while United States southern literary studies is also emerging from a similarly perceived backwardness problem, I fear that Barbara Ladd's essay ("Literary Studies: The Southern United States, 2005” [1628-39]), perhaps inadvertently, appears less interested in celebrating our field's new energies than in trying to contain them.

The problems with the essay are often but not always temporal. Particularly in a section labeled The Changing Profession, it does not do the field any favors in 2005 to say its "most salient problematics" are race and gender (1630). Furthermore, Ladd's take on gender is strangely heteronormative, as though major books by Minrose Gwin, John Howard, Tara McPherson, and Gary Richards, not to mention Howard's 1997 anthology Carryin' On in the Lesbian and Gay South, had not put queer issues on the field's front burner.

While Ladd seems to commence carefully and with appropriate critical distance from the old field-structuring categories of place, community, and so forth, she ends up classifying all these as "varieties of memory" and then contrasting southern literature with the "national project of forgetting" $(1629,1637)$. But if American exceptionalism is bad, surely southern exceptionalism, redolent of what Freud called the narcissism of small differences, is bad too. (If it is not, Ladd probably owes the broad PMLA audience a theoretical account of why not, given the widespread Americanist consensus about exceptionalisms.) And in any event, as the historians David Blight, W. Fitzhugh Brundage, and David Goldfield, among many others, have forcefully reminded us, by denying that the Civil War was about slavery (to cite but the most glaring counterexample), the white South has repeatedly presented not an alternative to but a frightening dependence on "the evasions offered by willed amnesias” (1637). 
The history of the field Ladd gives is at least suspect. John Bell Henneman was of the New South, Library of Southern Literature, "the South is purely American" school that sought to reunite white America after Reconstruction, but Louis D. Rubin, Jr., founded the field in much greater debt to the Nashville Agrarians, who rebelled bitterly against people like Henneman. And in what other discipline would a writer, invoking the way the field is "[t]oday" (1629), cite work from 1972 (George C. Kent) and 1983 (C. Hugh Holman, Fred Hobson)? Yet Ladd ignores completely much of the truly revisionary "new southern studies" work of the past seven years, such as Houston Baker's Turning South Again and Critical Memory, Tara McPherson's Reconstructing Dixie, and George Handley's crucial Postslavery Literatures in the Americas. Nichols's copious supplementary bibliography offers an instructive contrast. When Ladd alludes to works that really take a hammer to old categories-for example, despite its half-heartedly optimistic conclusion, Scott Romine's The Narrative Forms of Southern Community - she claims they merely "energize" the field by "reconceptualiz[ing]" these old categories (1636). Similarly, Ladd celebrates Yaeger's Dirt and Desire (in a single paragraph, though it is by far the most visionary book under review) but glosses over Yaeger's aggravation not with Cleanth Brooks but with white boomer feminist Susan Goodman. In what is discussed and what is not, I am not sure the impatient, even insurgent, nature of so much of the best new work is so easily dispelled.

Along these lines, and perhaps most disturbingly, Ladd seeks to reconceptualize new southern studies as "post-civil rights era southern studies" (1631). Especially when coupled with her dubious claim that the impact of the civil rights movement was "immediate and lasting" on the field (1629), such a move would effectively define "new southern studies" out of existence and defang the revisionary energy Baker and Dana Nelson sought to give it when they coined the phrase as a rallying cry in their 2001 introduction to Violence, the Body, and "The South." Logically, that is, Ladd's redefinition permits any southern literary scholarship since the 1960s, even the 1985 History of Southern Literature, which devoted an entire chapter to antebellum white southern poetry exclusive of Poe while barely touching on slave narratives, to constitute new southern studies. Finally, Ladd's reference to a "cultural or ideological sublime" (1636) presents honest and widespread frustration with the self-serving complacencies of seventy years of scholarship as mere anxiety of influence. No doubt there's some of that, but more is going on.

Surely one lesson of southern history is that "self-preserving face-off[s]" (1636), willed amnesias, and other lost causes are not the exclusive province of progressives. Academia is no exception, but the big loser in such cases is most often the field itself. Whereas Ladd begins with a warning about " $[\mathrm{t}]$ he greatest mistake made in judging southern literature, even by its friends" (1628), Nichols begins with a sense of excitement: "Medieval studies are big-in fact, have rarely been livelier ... or more controversial" (422). That sense of excitement-even that exact claim-is equally true of southern studies, at least as practiced by such scholars as Baker, Gwin, Handley, Howard, McPherson, Richards, Romine, Hosam M. AboulEla, Eric Gary Anderson, Martyn Bone, Deborah Cohn, Leigh Anne Duck, Judith Jackson Fossett, Jennifer Greeson, Adam Gussow, Matthew Pratt Guterl, Katherine Henninger, John T. Matthews, Riché Richardson, and Nicole Waligora-Davis. Thanks to them and others, United States southern studies, far from gazing into the navel of memory, is pushing the boundaries of American and inter-American studies, postcolonial theory, queer studies, cultural studies, and media, visual culture, and globalization studies. PMLA readers need to know so, and this influential hard work deserves better than to be consigned, mainly anonymously, to some distant "horizon" of the discipline (1633). Though sometimes frightening, controversy is good for a field; it's hard to find liveliness without it.

\section{Jon Smith \\ University of Montevallo}

\section{Reply:}

Jon Smith is a valued colleague. He and I frequently disagree. I was surprised, however, to see 